\title{
Use of biogas biscuit meal EKPO-EB for agricultural biogas plant for substitution of energy crops utilization with organic waste
}

\author{
Kateřina Chamrádová, Jiří Rusín \\ VŠB - Technical University of Ostrava, Centre for Environmental Technologies-9350, 17. listopadu 15, Ostrava - Poruba \\ 708 33, e-mail: katerina.chamradova@vsb.cz, jiri.rusin@vsb.cz
}

\begin{abstract}
A laboratory experiment of two-stage mesophilic, low-dry mass, anaerobic digestion was carried out, focused on verifying the benefit of processing the biscuit meal EKPO-EB instead of triticale silage Agostino (GPS) and corn silage LG3266 in a regular batch for the agricultural biogas station in Pustějov. While anaerobic digestion of ensilages is largely difficult due to the content of lignocellulose, biscuit meal provides a high yield of biogas or methane, respectively, thanks to its high content of simple saccharides and lipids. When the original GPS (or the replacement EKPO-EB, respectively) represented $0.81 \%$ of weight of the daily input mixture dose for the first stage, the rise in volumetric methane production was $20 \%$ which is significant. The biscuit meal EKPO-EB decomposes almost completely in the first stage. Later, when the EKPO-EB represented $1.63 \%$ of weight of the daily input mixture dose for the first stage, the rise in volumetric methane production was $54 \%$ in the first stage and $16 \%$ in the second stage.
\end{abstract}

Keywords: confectionary biowaste, biogas biscuit meal EKPO-EB, anaerobic digestion.

\section{INTRODUCTION}

In the past few decades especially in advanced countries, the benefits of anaerobic digestion have been observed in agriculture and also in the area of the inactivation and use of industrial, municipal and food biowaste ${ }^{1,2,3}$.

A wide range of various biologically degradable waste is created in the food industry, which is largely landfilled. The Directive No. 1999/31/EC on the landfill of waste ${ }^{4}$ imposes on member states the duty to reduce the amount of biologically degradable waste landfilled to $75 \%$ of the weight of this type of waste created in 1995 by 2010 , to $50 \%$ of the weight by 2013 , and to $35 \%$ not later than by 2020 .

Although the Czech Republic can use a four-year postponement in the fulfilment of these limits, it will not avoid future problems when complying with the requirements of the directive. Only a small part of biowaste from food industry productions is used for feeding purposes, and only a small part is used for biogas production, as well. This waste has long been considered only as materials for disposal, not as a potential for side raw materials of a high value ${ }^{5,6}$.

Waste generated by confectionery production is classified in Group 2, Paragraph (h) according to Annex 1 to Decree No. 453/2008 Coll. ${ }^{7}$, "which stipulates the types, methods of utilization, and parameters of biomass for purposes of supporting the generation of electricity from biomass". This waste may be processed by agricultural BGS classified both in the category of anaerobic processes AF2, and also $A F 1$. The requirement of hygienization pursuant to Regulation (EC) No. 1774/2002 ${ }^{8}$, or pursuant to Decree No. 341/2008 Coll. of the Ministry of the Environment "on biowaste“9, respectively, does not apply to this waste.. For example, in Northern Moravia, the biscuit meal EKPO-EB can be processed at the biogas stations of Pustějov (AF1) or Klokočov (AF2).

The biscuit meal EKPO-EB was delivered for the experiment by CERVUS, s.r.o. Olomouc. The meal was prepared by targeted mixing of food industry biowaste, particularly waste unsuitable for feeding in terms of microbiology (chocolate mass, chocolate fillings, fatty pastries, etc.), to show a higher biogas production than the standard biscuit meal EKPO ${ }^{10}$ for feeding, which is often processed to produce biogas, as well, together with other unfed residues from agricultural farms. Compared to EKPO, EKPO-EB contains a higher portion of lipids and almost no fibrous substances such as cocoa peels. The exact composition of EKPO-EB was not provided by the manufacturer. It was confirmed that EKPO-EB $1 \mathrm{~kg}$ can be used to obtain $0.900 \mathrm{~m}_{\mathrm{N}}^{3}$ to $1.000 \mathrm{~m}_{\mathrm{N}}{ }^{3}$ of biogas, or approx. $0.450 \mathrm{~m}_{\mathrm{N}}^{3}$ to $0.500 \mathrm{~m}_{\mathrm{N}}^{3}$ of methane, respectively ${ }^{11}$.

The biogas station Pustějov I is a classical agricultural biogas station operated using the wet anaerobic process, and with the installed electric power of $0.5 \mathrm{MW}^{12}$. In 2013, anaerobic digestion was implemented in two stages at this station, while one half of the total hydraulic biomass retention time fell on each of the reaction stages (active reaction volume of $2.100 \mathrm{~m}^{3}$ ). The HRT of each stage was approximately 18 days. Based on the rules of operation of this BGS, the first stage may be loaded with the maximum of 3.5 of organic dry mass per $1 \mathrm{~m}^{3}$ and day. Table 1 shows the composition of the input mixture at BGS Pustějov I. This composition of the input mixture corresponds (with regular daily dosage of $118 \mathrm{~m}^{3}$ ) to the production of approx. $6.000 \mathrm{~m}^{3} \cdot \mathrm{d}^{-1}$ of biogas with $\mathrm{CH}_{4} 60$ vol. \%, or the average of $13.320 \mathrm{kWh} \cdot \mathrm{d}^{-1}$ of electric energy, respectively.

\section{MATERIAL AND METHODS}

\section{Material}

Substrate triticale silage Agostino (GPS) was also obtained from agricultural biogas station Pustějov. The material isn't often used for biogas production in the $\mathrm{CR}$, but it is commonly used in other countries ${ }^{13,14}$. The Triticale silage is characterized by high share of $13.8 \%$ starch and fiber content of $24.01 \%$ by weight.

Corn silage LG3266 was also obtained from agricultural biogas station Pustějov. Unlike the substrate triticale silage Agostino it is a biogas substrate commonly used in agricultural biogas stations in the Czech Republic 
Table 1. Parameters of co-substrates

\begin{tabular}{|c|c|c|c|c|}
\hline \multirow{2}{*}{ Co-substrate } & $\mathrm{pH}$ & TS & VS & $\mathrm{VS}_{\mathrm{TS}}$ \\
\hline & - & wt.\% & wt.\% $\%$ & wt. \% Ts \\
\hline Cattle slurry from dairy-farm Zemspol Studénka, a.s. & 7.4 & 4.34 & 3.39 & 78.04 \\
\hline Pig slurry from biogas station Kujavy & 7.1 & 2.31 & 1.89 & 81.78 \\
\hline Corn silage LG3266 & 4.3 & 33.62 & 32.27 & 95.99 \\
\hline Triticale silage Agostino (GPS) & 4.5 & 36.98 & 35.73 & 96.63 \\
\hline Scrap grain triticale Agostino & - & 86.77 & 84.90 & 97.84 \\
\hline Sugar beet cutting & - & 21.26 & 20.42 & 96.07 \\
\hline Rinse water glycerol (G-water) from the company GLASSOR s.r.o. Liberec & 7.1 & 12.52 & 9.88 & 78.91 \\
\hline Feed mixture into the model P1 (without recycling) & 6.0 & 9.59 & 8.87 & 92.52 \\
\hline Digestate from the model P1 (recycle) & 7.9 & 5.17 & 3.66 & 70.86 \\
\hline Digestate from the model P2 & 8.0 & 4.75 & 3.22 & 67.73 \\
\hline Biscuit meal EKPO-EB & - & 90.50 & 89.10 & 98.40 \\
\hline
\end{tabular}

Note: TS - total solids, VS - volatile solids, $\mathrm{VS}_{\mathrm{TS}}$ - loss on ignition of the dry matter.

and especially in Germany. It is characterized by a high proportion of starch $23.8 \%$ and fiber content of $24.82 \%$ by weight.

Biogas biscuit meal EKPO-EB was supplied by CERVUS, Ltd. Olomouc. EKPO-EB was prepared by mixing the targeted biological waste from the food industry, especially waste microbiologically unsuitable for feeding (mass of chocolate, chocolate fillings, fat dough etc.). EKPO -EB contains fiber $(0.40 \%)$, a higher percentage of lipids $(16.40 \%)$ and starch $(38.80 \%)$. The rest of the incoming raw mixture weren't analysed in detail. At this time biscuit meal EKPO serves primarily as a valuable additive in feed mixtures, but due to the gradual reduction of agricultural production the biscuit meal and other valuable feed are becoming waste increasing range that is removed / disposed of in landfills. The European Union mandates to reduce of biodegradable waste going to landfill.

\section{Laboratory model}

Two model fermenters of the same construction with a loading volume of $0.06 \mathrm{~m}^{3}$ and continuous stirring (Fig. 1) were used to carry out long-term tests of continuous mesophilic anaerobic co-digestion. The models were implemented at a scale of 1:35000. The average digestion temperature was kept at $40 \pm 3^{\circ} \mathrm{C}$ with a continuous run of the low-speed stirrer $\left(24 \mathrm{~min}^{-1}\right)$. The measurements of biogas production were carried out with laboratory drum-type gas flow meters and the composition of the biogas was measured daily by a mobile analyzer with IR and electrochemical sensors and occasionally checked by gas chromatography. The total solids (TS), volatile solids (VS), $\mathrm{pH}$ and volumetric mass (bulk density) were measured for input mixtures and digestates twice a week. After each digestion test, average values of the parameters characterizing the input mixture, digestate, biogas and process itself were calculated.

\section{ANAEROBIC DIGESTION TEST}

The suspensions were taken from BGS Pustějov in the morning hours, transported, and inserted in the model the same day. The first reaction stage of the model was filled with the suspension from the first reaction stage of BGS Pustějov. The second reaction stage of the model was filled with the suspension from the second reaction stage of BGS Pustějov. The temperature at the beginning of the test was $30^{\circ} \mathrm{C}$, and as early as during 10 hours, the required and further maintained temperature of $40 \pm 1^{\circ} \mathrm{C}$. From day 2 of the model test (for 44 days), the model was maintained with single daily dosing of the input mixture according to the established formula of the BGS. An appropriate amount of the input mixture was thus dosed in the first stage, while the digestate from the first stage was dosed in the second stage as a single daily dose. The digestate of the second stage was partially recycled in the input mixture for the first stage (see Table 2), and partially poured away. Dosing did not take place on weekends and holidays, and therefore the mean hydraulic retention time of the biomass in individual reaction stages is longer than that of the BGS Pustějov operation $(25+25$ days in the model vs. $18+18$ days at the BGS).

The experiment was divided in three periods: $A, B$ and $C$. The duration of each test period was 44 days. In period $A$, the input mixture was dosed according to the established formula of BGS Pustějov. In period $B$, mixture containing EKPO-EB meal instead of the Triticale silage Agostino (GPS) was dosed. In period $C$, the dose of EKPO-EB was doubled, and the corn

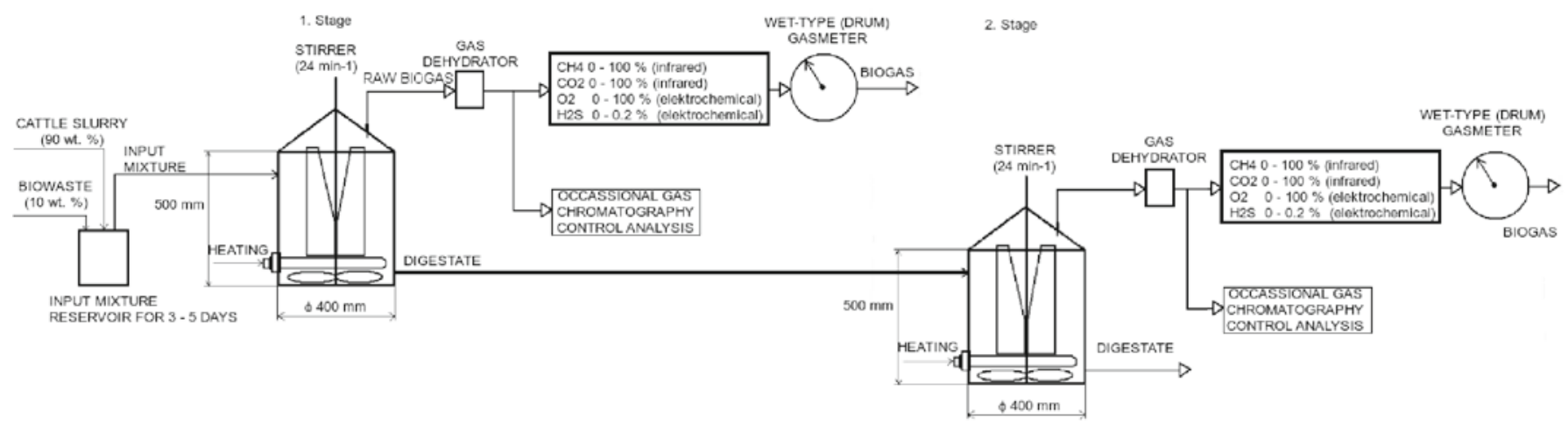

Figure 1. Layout of laboratory apparatus 
Table 2. The composition of the daily feed mixture (operation BGS Pustějov versus model). Period A - according to settled method by BGS Pustějov

\begin{tabular}{|c|c|c|c|c|c|c|c|}
\hline \multirow{3}{*}{ Substrát } & \multicolumn{5}{|c|}{$\begin{array}{l}\text { Operation of BGS Pustějov } \\
\text { Reaction volume } 2,100 \mathrm{~m}^{3}\end{array}$} & \multirow{2}{*}{\multicolumn{2}{|c|}{$\begin{array}{c}\text { Laboratory model } \\
\text { Reaction volume } 0.06 \mathrm{~m}^{3} \\
\text { Substrate }\end{array}$}} \\
\hline & \multicolumn{3}{|c|}{ Substrate } & \multicolumn{2}{|c|}{ TS } & & \\
\hline & $\% \mathrm{hm}$. & $\mathrm{kg}$ & $\mathrm{m}^{3}$ & $\% \mathrm{hm}$. & $\mathrm{kg}$ & $\mathrm{kg}$ & $\mathrm{m}^{3}$ \\
\hline Cattle slurry & 32.96 & 40,560 & 40.00 & 8.00 & 3,240 & 1.16 & 0.00114 \\
\hline Pig slurry & 32.76 & 40,320 & 40.00 & 6.00 & 2,420 & 1.15 & 0.00114 \\
\hline Corn silage LG3266 & 12.19 & 15,000 & 10.71 & 29.80 & 4,470 & 0.43 & 0.00031 \\
\hline Triticale silage Agostino (GPS) & 0.81 & 1,000 & 0.71 & 42.00 & 420 & 0.03 & 0.00002 \\
\hline Scrap grain triticale Agostino & 1.63 & 2,000 & 1.43 & 86.00 & 1,720 & 0.06 & 0.00004 \\
\hline Sugar beet cutting & 4.06 & 5,000 & 3.57 & 20.00 & 1,000 & 0.14 & 0.00010 \\
\hline Rinse water glycerol (G-water) & 0.81 & 1,000 & 1.00 & 5.00 & 50 & 0.03 & 0.00003 \\
\hline $\begin{array}{l}\text { Dilutive digestate (from the } 2^{\text {nd }} \\
\text { Fermenter-recycle }\end{array}$ & 14.77 & 18,180 & 18 & 4.00 & 730 & 0.52 & 0.00051 \\
\hline Dose of an input mixture & & $\mathrm{kg}$ & $\mathrm{m}^{3}$ & $\% \mathrm{hm}$. & $\mathrm{kg}$ & $\mathrm{kg}$ & $\mathrm{m}^{3}$ \\
\hline Total daily doses into $1^{\text {st }}$ stage & & 123,060 & 115.43 & 11.42 & 14,050 & 3.52 & 0.00330 \\
\hline
\end{tabular}

Note: In the case of liquid substrates BGS supplied information about the quantity in $\mathrm{m}^{3}$ and in the case of the rigid substrates in kg.

silage LG3266 portion was also replaced with the meal (see Table 4). The dose of EKPO-EB meal $30 \mathrm{~g}$ in the model matches approximately $1,000 \mathrm{~kg}$ of the meal in the BGS operation. Table 1 shows main parameters of the co-substrates. Tables 2-4 show the composition of the input mixture for the periods $A, B$ and $C$.

\section{RESULTS AND DISCUSSION}

\section{Period A - Co-fermentation of the input mixture based on the established formula of BGS Pustějov}

In the first reaction stage, the mean amount of $0.124 \mathrm{~m}_{\mathrm{N}}{ }^{3} \cdot \mathrm{d}^{-1}$ of biogas, containing 54 vol. \% of methane, was produced in this period through cofermentation of the input mixture having the volumetric weight of approx. $1,020 \mathrm{~kg} \cdot \mathrm{m}^{-3}$, mean $\mathrm{pH}$ of 6.5 , total dry mass content TS $9.3 \mathrm{wt} . \%$, organic dry mass content VS $8.1 \mathrm{wt} \%$, volumetric load of the fermenter $3.36 \mathrm{~kg}_{\mathrm{VS}} \cdot \mathrm{m}^{-3} \cdot \mathrm{d}^{-1}$ and theoretical hydraulic retention time of 25 days. Specific biogas production amounted to $0.050 \mathrm{~m}_{\mathrm{N}}^{3} \cdot \mathrm{kg}^{-1}$, and specific methane production amounted to $0.330 \mathrm{~m}_{\mathrm{N}}^{3} \cdot \mathrm{kg}_{\mathrm{Vs}}{ }^{-1}$, respectively. The mean content of total dry mass obtained in the reactor was 4.8 wt. $\%$

In the second reaction stage, the digestate of the first stage, having the volumetric weight of approx. 1,016 $\mathrm{kg} \cdot \mathrm{m}^{-3}$, mean $\mathrm{pH}$ of 8.0 , TS $4.8 \mathrm{wt} . \%$, VS $3.4 \mathrm{wt} . \%$, volumetric load of the fermenter $1.41 \mathrm{kgvs} . \mathrm{m}^{-3} \cdot \mathrm{d}^{-1}$ and theoretical hydraulic retention time of 25 days, provided the mean amount of $0.018 \mathrm{~m}_{\mathrm{N}}^{3} \cdot \mathrm{d}^{-1}$ of biogas containing 52 vol.\% of methane. Specific biogas production amounted to $0.007 \mathrm{~m}_{\mathrm{N}}{ }^{3} \cdot \mathrm{kg}^{-1}$, and specific methane production amounted to $0.114 \mathrm{~m}_{\mathrm{N}}^{3} \cdot \mathrm{kg}_{\mathrm{Vs}}{ }^{-1}$, respectively. The mean content of total dry mass obtained in the reactor was $4.6 \mathrm{wt} . \%$

\section{Period B - Triticale silage Agostino (GPS) replaced with biscuit meal EKPO-EB}

In the first reaction stage, the mean amount of $0.147 \mathrm{~m}_{\mathrm{N}}{ }^{3} \cdot \mathrm{d}^{-1}$ of biogas, containing $54 \mathrm{vol} . \%$ of methane, was produced in this period through co-fermentation of the input mixture having the volumetric weight of approx. $1,021 \mathrm{~kg} \cdot \mathrm{m}^{-3}$, mean $\mathrm{pH}$ of 6.2 , total dry mass content TS 9.5 wt.\%, organic dry mass content VS 8.3 wt.\%, volumetric load of the fermenter $3.39 \mathrm{~kg}_{\mathrm{vs}} \cdot \mathrm{m}^{-3} \cdot \mathrm{d}^{-1}$ and theoretical hydraulic retention time of 25 days. A marked

Table 3. The composition of the daily feed mixture (operation BGS Pustějov versus model). Period B - Triticale silage Agostino (GPS) replaced with biscuit meal EKPO-EB

\begin{tabular}{|c|c|c|c|c|c|c|c|}
\hline \multirow{3}{*}{ Substrát } & \multicolumn{5}{|c|}{$\begin{array}{l}\text { Operation of BGS Pustějov } \\
\text { Reactive volume } 2,100 \mathrm{~m} 3\end{array}$} & \multirow{2}{*}{\multicolumn{2}{|c|}{$\begin{array}{c}\text { Laboratory model } \\
\text { Reactive volume } 0.06 \mathrm{~m} 3 \\
\text { Substrate }\end{array}$}} \\
\hline & \multicolumn{3}{|c|}{ Substrate } & \multicolumn{2}{|c|}{ TS } & & \\
\hline & $\% \mathrm{hm}$. & $\mathrm{kg}$ & $\mathrm{m} 3$ & $\% \mathrm{hm}$. & $\mathrm{kg}$ & $\mathrm{kg}$ & $\mathrm{m} 3$ \\
\hline Pig slurry & 32.76 & 40,320 & 40.00 & 6.00 & 2,420 & 1.15 & 0.00114 \\
\hline Corn silage LG3266 & 12.19 & 15,000 & 10.71 & 29.80 & 4,470 & 0.43 & 0.00031 \\
\hline EKPO-EB & 0.81 & 1,000 & 0.71 & 93.50 & 940 & 0.03 & 0.00002 \\
\hline Sugar beet cutting & 4.06 & 5,000 & 3.57 & 20.00 & 1,000 & 0.14 & 0.00010 \\
\hline $\begin{array}{l}\text { Rinse water glycerol (G- } \\
\text { water) }\end{array}$ & 0.81 & 1,000 & 1.00 & 5.00 & 50 & 0.03 & 0.00003 \\
\hline $\begin{array}{l}\text { Dilutive digestate (from the } \\
\text { 2nd Fermenter - recycle) }\end{array}$ & 14.77 & 18,180 & 18 & 4.00 & 730 & 0.52 & 0.00051 \\
\hline \multicolumn{2}{|c|}{$\begin{array}{l}\text { Dose of an input mixture } \\
\text { Total daily doses into } 1 \text { st stage }\end{array}$} & $\mathrm{kg}$ & $\mathrm{m} 3$ & $\% \mathrm{hm}$. & $\mathrm{kg}$ & $\mathrm{kg}$ & m3 \\
\hline
\end{tabular}

Total daily recycling into $2^{\text {nd }}$ stage (the same volume) 
increase of biogas production was observed within 5 days from the change in the input mixture composition. The mean content of total dry mass in the reactor reached 4.5 wt. \%, which is a value slightly lower compared to period A; this may have been caused also by different vertical distribution of undissolved particles of the dry mass in the reactor having an effect on the collection of digestate samples. The benefit of processing the biscuit meal was evident considering that mean biogas production rose to $0.061 \mathrm{~m}_{\mathrm{N}}^{3} \cdot \mathrm{kg}^{-1}$ and specific production of methane rose to $0.393 \mathrm{~m}_{\mathrm{N}}^{3} \cdot \mathrm{kg}_{\mathrm{vs}}{ }^{-1}$, respectively. The graphic depiction of the test is presented in Figure 2.
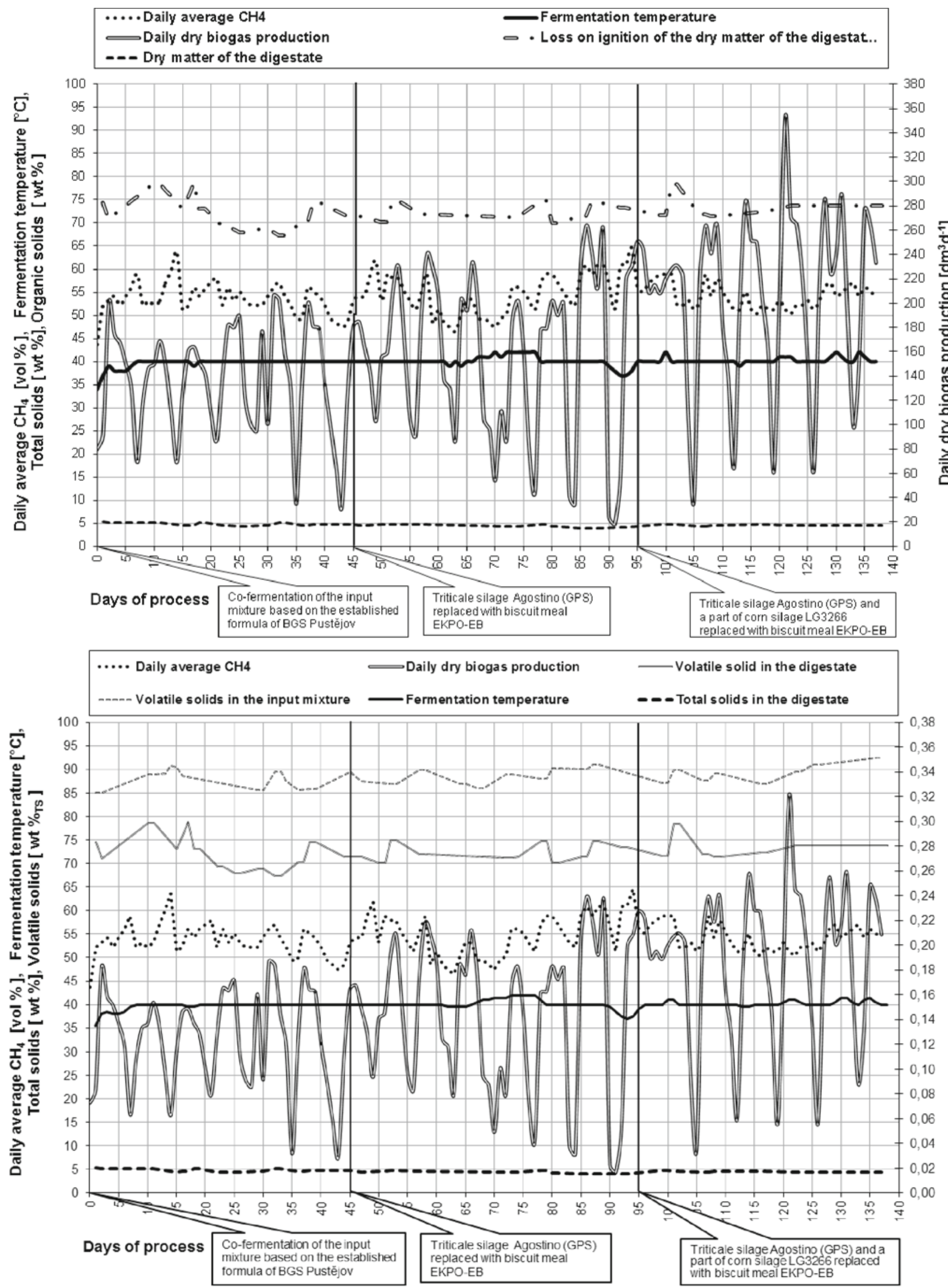

Figure 2. Cofermentation in model of $1^{\text {st }}$ reactive stage 
In the second reaction stage, the digestate of the first stage, having the volumetric weight of approx. 1,017 $\mathrm{kg} \cdot \mathrm{m}^{-3}$, mean $\mathrm{pH}$ of 8.1 , TS $4.5 \mathrm{wt} \%$, VS $3.2 \mathrm{wt} . \%$, volumetric load of the fermenter $1.29 \mathrm{kgvs} \cdot \mathrm{m}^{-3} \cdot \mathrm{d}^{-1}$ and theoretical hydraulic retention time of 25 days, provided the mean amount of $0.019 \mathrm{~m}_{\mathrm{N}}{ }^{3} \cdot \mathrm{d}^{-1}$ of biogas containing 52 vol. $\%$ of methane. Specific biogas production amounted to $0.008 \mathrm{~m}_{\mathrm{N}}^{3} \cdot \mathrm{kg}^{-1}$, and specific methane production amounted to $0.125 \mathrm{~m}_{\mathrm{N}}^{3} \cdot \mathrm{kg}_{\mathrm{vs}}{ }^{-1}$, respectively. The mean content of total dry mass obtained in the reactor decreased to the mean value of $3.9 \mathrm{wt} . \%$. The graphic course of the test is shown in Figure 3.

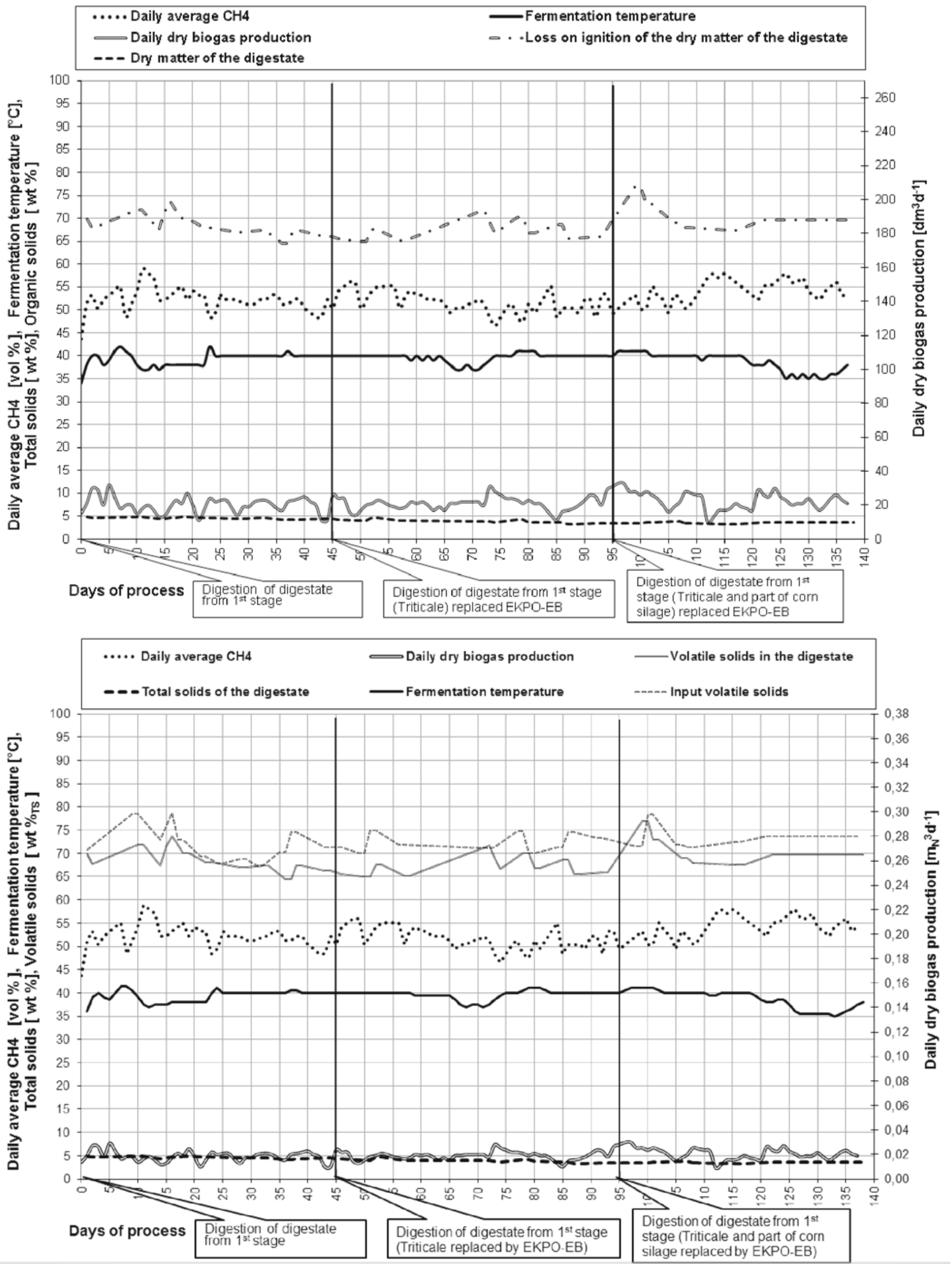

Figure 3. Cofermentation in model of $2^{\text {nd }}$ reactive stage 
Compared to period A, biogas production rose by $19 \%$ in period B in the first reaction stage, while the volumetric portion of methane remained virtually preserved at $54 \%$, i.e. methane production rose approx. by $20 \%$. In the second reaction stage, biogas production rose very slightly by $1.3 \%$, while the portion of methane did not drop below 51.7 vol. $\%$, i.e. methane production rose approx. by $0.1 \%$. These results clearly show that the biscuit meal EKPO-EB was decomposed virtually completely in the first fermentation stage already. Considering that the original triticale silage (or the replacement EKPO-EB, respectively), formed only $0.81 \%$ of the weight of the daily input mixture dose for the first stage, the total rise in methane production is significant. In practical implementation of the first stage at BGS Pustějov, the proposed (modelled) change would mean processing more dry mass by approx. $520 \mathrm{~kg}$ daily. At the same time, the total dry mass content of the input mixture, using EKPO-EB instead of triticale silage, would rise only by 0.4 to $0.7 \mathrm{wt} . \%$. The maximum volumetric load of the first fermentation stage of $3.5 \mathrm{~kg}_{\mathrm{vs}} \cdot \mathrm{m}^{-3} \cdot \mathrm{d}^{-1}$, as determined by the rules of operation, would not be exceeded because a reserve remains; however, the dry mass share of the targeted biomass production would decrease below $50 \mathrm{wt} . \%$, which would require switching the BGS from the more advantageous mode AF1 to the mode AF2 (characterized by a lower purchase price of electric energy).

Period C - Triticale silage Agostino (GPS) and a part of corn silage LG3266 replaced with biscuit meal EKPO-EB

In this period, the input mixture containing $0,057 \mathrm{~kg}$ of biogas biscuit meal EKPO-EB was dosed for 44 days. This model dose corresponds to $2,000 \mathrm{~kg}$ of the meal in the BGS Pustějov operation, while $1,000 \mathrm{~kg}$ of the meal replace all triticale silage Agostino (GPS), and the other $1,000 \mathrm{~kg}$ replace a part of the corn silage LG3266 dose.

In the first reaction stage, the mean amount of $0.188 \mathrm{~m}_{\mathrm{N}}^{3} \cdot \mathrm{d}^{-1}$ of biogas, containing $54 \mathrm{vol} \%$ of methane, was produced in this period through co- fermentation of the input mixture having the volumetric weight of approx. $1,022 \mathrm{~kg} \cdot \mathrm{m}^{-3}$, mean $\mathrm{pH}$ of 6.1 , total dry mass content TS $10.2 \mathrm{wt} . \%$, organic dry mass content VS 9.1 wt.\%, volumetric load of the fermenter $3.87 \mathrm{~kg}_{\mathrm{vs}} \cdot \mathrm{m}^{-3} \cdot \mathrm{d}^{-1}$ and theoretical hydraulic retention time of 24 days. A marked increase of biogas production was observed within 4 days from the change in the input mixture composition. The mean content of total dry mass in the reactor rose slightly to $4.6 \mathrm{wt} . \%$. The benefit of processing the biscuit meal was evident again considering that mean biogas production rose to $0.074 \mathrm{~m}_{\mathrm{N}}^{3} \cdot \mathrm{kg}^{-1}$ and specific production of methane rose to $0.442 \mathrm{~m}_{\mathrm{N}}^{3} \cdot \mathrm{kg}_{\mathrm{vs}}{ }^{-1}$, respectively.

In the second reaction stage, the digestate of the first stage, having the volumetric weight of approx. 1020 $\mathrm{kg} \cdot \mathrm{m}^{-3}$, mean $\mathrm{pH}$ of 8.1 , TS $4.6 \mathrm{wt} . \%$, VS $3.2 \mathrm{wt} . \%$, organic load of the fermenter $1.43 \mathrm{kgvs} \cdot \mathrm{m}^{-3} \cdot \mathrm{d}^{-1}$ and theoretical hydraulic retention time of 24 days, provided the mean amount of $0.021 \mathrm{~m}_{\mathrm{N}}^{3} \cdot \mathrm{d}^{-1}$ of biogas containing 54 vol.\% of methane. Specific biogas production amounted to $0.008 \mathrm{~m}_{\mathrm{N}}^{3} \cdot \mathrm{kg}^{-1}$, and specific methane production amounted to $0.131 \mathrm{~m}_{\mathrm{N}}{ }^{3} \cdot \mathrm{kg}_{\mathrm{Vs}}{ }^{-1}$, respectively. The mean content of total dry mass in the reactor decreased to the mean value of 3.5 wt. $\%$

Compared to period A, biogas production rose by $52 \%$ in period $\mathrm{C}$ in the first reaction stage, while the volumetric portion of methane remained virtually preserved at $54 \%$, i.e. methane production rose approx. by $54 \%$. In the second stage a considerable rise in biogas production by $13 \%$ was seen in period $\mathrm{C}$ compared to period $\mathrm{A}$, and the volumetric portion of methane rose to $54 \%$, leading to a rise in methane production by approx. $16 \%$.

If we consider that all of the input organic solids VS was biodegradable and the correction factor of water consumption by the anaerobic process was 0.85 (mean value of the indicated range typically from 0.7 to 1.0 ), see Robertson ${ }^{15}$, than removal efficiency of biodegradable organic solids is BVS $68.0 \%$ organic solids for period A, $79.9 \%$ for period B and $89,4 \%$ for period C. The value of the input BVS was not specified, because the

Table 4. The composition of the daily feed mixture (operation BGS Pustějov versus model). Period C - Triticale silage Agostino (GPS) and a part of corn silage replaced with biscuit meal EKPO-EB

\begin{tabular}{|c|c|c|c|c|c|c|c|}
\hline \multirow{3}{*}{ Substrát } & \multicolumn{5}{|c|}{$\begin{array}{l}\text { Operation of BGS Pustějov } \\
\text { Reactive volume } 2,100 \mathrm{~m}^{3}\end{array}$} & \multirow{2}{*}{\multicolumn{2}{|c|}{$\begin{array}{c}\begin{array}{c}\text { Laboratory model } \\
\text { Reactive volume } 0.06 \mathrm{~m}^{3}\end{array} \\
\text { Substrate } \\
\end{array}$}} \\
\hline & \multicolumn{3}{|c|}{ Substrate } & \multicolumn{2}{|c|}{ TS } & & \\
\hline & $\% \mathrm{hm}$. & $\mathrm{kg}$ & $\mathrm{m}^{3}$ & $\% \mathrm{hm}$. & $\mathrm{kg}$ & $\mathrm{kg}$ & $\mathrm{m}^{3}$ \\
\hline Cattle slurry & 32.96 & 40,560 & 40.00 & 8.00 & 3,240 & 1.16 & 0.00114 \\
\hline Pig slurry & 32.76 & 40,320 & 40.00 & 6.00 & 2,420 & 1.15 & 0.00114 \\
\hline Corn silage LG3266 & 11.38 & 14,000 & 10.00 & 29.80 & 4,170 & 0.40 & 0.00029 \\
\hline EKPO-EB & 1.63 & 2,000 & 0.71 & 93.50 & 1,870 & 0.06 & 0.00002 \\
\hline $\begin{array}{l}\text { Scrap grain triticale } \\
\text { Agostino }\end{array}$ & 1.63 & 2,000 & 1.43 & 86.00 & 1,720 & 0.06 & 0.00004 \\
\hline Sugar beet cutting & 4.06 & 5,000 & 3.57 & 20.00 & 1,000 & 0.14 & 0.00010 \\
\hline $\begin{array}{l}\text { Rinse water glycerol } \\
\text { (G-water) }\end{array}$ & 0.81 & 1,000 & 1.00 & 5.00 & 50 & 0.03 & 0.00003 \\
\hline $\begin{array}{l}\text { Dilutive digestate (from } \\
\text { the } 2^{\text {nd }} \text { Fermenter - } \\
\text { recycle }\end{array}$ & 14.77 & 18,180 & 18 & 4.00 & 730 & 0.52 & 0.00051 \\
\hline
\end{tabular}

Dose of an input mixture Total daily doses into $1^{\text {st }}$ stage

\begin{tabular}{|c|c|c|c|c|c|}
\hline $\mathrm{kg}$ & $\mathrm{m}^{3}$ & $\% \mathrm{hm}$. & $\mathrm{kg}$ & $\mathrm{kg}$ & $\mathrm{m}^{3}$ \\
\hline 123,060 & \multirow{2}{*}{117.58} & 12.35 & 15,200 & 3.52 & 0.0028 \\
\hline
\end{tabular}


content of gross lignin and others stable substances has not been analyzed.

Curve of during (loss of ignition) input mixture was added in the graph 1 . The content of organic substances in the reactor (loss of ignition) was relatively constant. Fluctuations in Graph 1 and 2 are largely made by especially problematic representative sampling of the rather than by actually happenning change.

In practical implementation of the BGS Pustějov, the procedure as per period $\mathrm{C}$ would require the processing of more dry mass by approx. $1,150 \mathrm{~kg}$ daily in the first stage compared to regular practice. The dry mass content in the input mixture would reach approx. $12.4 \%$, which should still cause no problems when pumping the mixture into the reactor. The benefit of EKPO-EB seems to be very substantial here.

\section{CONCLUSION}

Physical modelling of the two-stage mesophilic, low-dry mass, anaerobic digestion outlined the benefit of processing EKPO-EB-type biscuit meal for an agricultural biogas station Pustějov $\left(0.5 \mathrm{MW}_{\mathrm{e}}\right)$, as regards biogas and methane production. If approximately $1,000 \mathrm{~kg}$ of triticale silage is replaced with EKPO-EB daily, biogas production would rise by $810 \mathrm{~m}_{\mathrm{N}}^{3} \mathrm{~d}^{-1}$ and methane production would rise by approx. $437 \mathrm{~m}_{\mathrm{N}}^{3} \mathrm{~d}^{-1}$. The majority of biodegradable EKPO-EB meal mass would be converted to gas as early as in the first fermentation stage, while the digestate from both the first and second stages would show a slightly lower content of total dry mass, and it would be more homogeneous and more liquid. CERVUS, Ltd company supposes the application of biogas biscuit meal EKPO-EB in biogas stations in the Czech Republic not only in but also in the neighboring countries. They are also considering building their own fermenter.

\section{ACKNOWLEDGMENT}

This article was elaborated within the framework of the project Opportunity for young researchers, reg. no. CZ.1.07/2.3.00/30.0016, supported by the Operational Programme Education for Competitiveness and co-financed by the European Social Fund and the state budget of the Czech Republic. This work was financially supported by the Ministry of Education, Youth and Sports of the Czech Republic in the "National Feasibility Program I", project LO1208 "Theoretical Aspects of Energetic Treatment of Waste and Environment Protection against Negative Impacts (TEWEP)" (2014-2018).

\section{LITERATURE CITED}

1. Asia, I.O., Oladoja, N.A. \& Bamuza-Pemu, E.E. (2006). Treatment of textile sludge using anaerobic technology. Afr. J. Biotechnol. 5(18), 1678-1683. DOI: 10.5897/AJB06.114.

2. Jha, A.K., Li, J., Nies, L. \& Zhang, L. (2011). Research advances in dry anaerobic digestion process of solid organic wastes. Afr. J. Biotechnol. 10(65), 14242-14253. DOI: 10.5897/AJB11.1277.

3. Schulte, D.D. \& Luis, V. (1983). Kinetic analysis of anaerobic fermentation of dry beef cattle manure. Paper, Am. Soc. Agric. Engine., 83, 1-27.

4. Council Directive 1999/31/EC of 26 April 1999 on the landfill of waste. Official Journal L 182, 16/07/1999, pp. 1-19.
5. Ranade, D.R. et. al. (1989). Biogas from solid waste originated during biscuit and chocolate production. Biol. Wastes. 28(2), 157-161. DOI: 10.1016/0269-7483(89)90079-7.

6. Agyeman, F.O. \& Tao, W. (2014). Anaerobic co-digestion of food waste and dairy manure: Effects of food waste particle size and organic loading rate. J. Environ. Manage. 133, 268-274. DOI: 10.1016/j.jenvman.2013.12.016.

7. Decree No. 453/2008 Coll., which stipulates the types, methods of utilization, and parameters of biomass for purposes of supporting the generation of electricity from biomass. (in Czech).

8. Commission Regulation (EC) No 1774/2002 of the European Parliament and of the Council of 3 October 2002 laying down health rules concerning animal by-products not intended for human consumption.

9. Decree No 341/2008 Coll., on details on biodegradable waste disposal. (in Czech).

10. CERVUS s.r.o. [online]. [cit. 2014-12-11]. Accessible from: http://www.cervus.cz/CZ/pdf/12_EKPO.pdf (in Czech).

11. Rusín, J., Chamrádová, K., Obroučka., K. \& Kuča, R. (2012). Methane production during laboratory-scale co-digestion of cattle slurry with $10 \mathrm{wt}$ \% of various biowastes. Pol. J. Chem. Technol. 14(1), 14-20. DOI: 10.2478/v10026-012-0053-x.

12. ZEMSPOL STUDÉNKA a.s. [online]. [cit. 2014-12-11]. Accessible from: http://www.zemspolstudenka.cz/ (in Czech).

13. Jenson, E. \& Eckford, R. (2010). The Benefits of Triticale and the Potential Energy Content of Triticale Based ByProducts through Anaerobic Digestion. $2^{\text {nd }}$ Annual Canadian Farm \& Food Biogas Conference and Exhibition, 8-12 March 2010. London Convention Centre, London, Ontario Canada.

14. Teghammar et al. (2012). Straw anaerobic digestibility. BioResources 7(3), 3921-3934.

15. Robertson, J.B. \& Van Soest, P.J. (1981). In The Analysis of Dietary Fiber in Food (W. P. T. James \& O. Theander, eds.), Marcel Dekker Inc, New York, U.S.A. 